\title{
Grammar Translation Method in ESP: Traditions and Innovations
}

\author{
Tatiana Sallier ${ }^{1, *} \&$ Tatiana Samsonova ${ }^{2}$ \\ ${ }^{1}$ University associated with Inter-Parliamentary Assembly of EurAsEC, Russian Federation \\ ${ }^{2}$ Academy of National Economy and Public Administration, Russian Federation \\ *Correspondence: University associated with Inter-Parliamentary Assembly of EurAsEC, Russian Federation. E-mail: \\ tatiana_sallier@mail.ru
}

Received: November 27, 2021

Accepted: January 10, 2022 Online Published: January 19, 2022

doi:10.5430/ijelt.v9n1p40

URL: https://doi.org/10.5430/ijelt.v9n1p40

\begin{abstract}
The article is devoted to the role of grammar in an ESP class - to students who don't specialize in English and need English primarily for professional reading. The authors argue that the most important language skill in English for special purposes in the framework of tertiary education is academic reading, which serves as a basis for developing academic speaking and academic writing skills. Teaching academic reading is impossible without a formal and systematic study of grammar. The principal grammatical phenomena needing special attention are outlined and several types of exercises which can be used in teaching grammar are recommended. It is shown that in some cases grammatical analysis provides cues for contextual guessing.
\end{abstract}

Keywords: grammar, reading, exercises, contextual guessing, English for special purposes

\section{Introduction}

The purpose of the article is to analyze the main trends in teaching grammar in higher education institutions to students who don't major in English or foreign languages and who need English for reading special literature as well as for professional oral communication. This sphere of teaching English is usually referred to as English for special purposes (ESP). The ESP audience can be described as students of technical, scientific or scholastic tertiary education institutions who have limited knowledge of English at the intermediate level and need the language for professional purposes. In the present article, the authors try to establish the role of grammar in ESP teaching and learning.

\section{Method}

The research was based on comparing the textbooks based on grammar translation method and those developing oral skills; the method of contextual analysis was also used to demonstrate in which spheres grammar translation method is best applicable and which syntactic structures are impossible to understand without grammatical analysis.

The authors also relied on their own experience, having taught English for Special purposes for over 50 years, and having ample opportunity to compare the existing teaching methods.

\section{Results}

Professional reading is the most important skill for adult ESP learners. Grammar translation method is an important element in teaching adult When used alongside other methods and based on materials related to the learners' field of knowledge, grammar translation method becomes a useful tool in teaching ESP. 


\section{Discussion}

\subsection{Basic Skills Necessary for Adult ESP Learners}

There is strong prejudice about grammar and its role in learning a foreign language, and the Internet is full of advertisements offering to teach "English without grammar"(Note 1)

There are two aspects in grammar - active grammar to be used in oral communication and a grammar of complicated scientific or scholastic texts, replete with complex syntactic constructions and professional terms. The first type of grammar is taught in secondary schools, the second type is a grammar necessary for decoding complicated texts.

It can be seen that most textbooks which have appeared on the market recently concentrate on active skills, valuable in developing speaking, but of little use in teaching reading.(Note 2) The lexis in these textbooks is limited to such topics as tourism, leisure, sports, home life and so on.(Vince 2009) They are invaluable for developing oral skills, but offer little help in learning/teaching to read a complicated scientific or scholastic text.

Turning to the type of grammar necessary for reading complicated materials we must find out which language skills are most important for professionals in technology, science and humanities.

The authors consider that in the framework of tertiary education reading is the most important of the four skills necessary to master in the language acquisition process - reading, listening, writing and speaking - the most important skill is reading.

It seems that for future engineers, scientists and scholars being able to read in English is paramount. It is through reading that a researcher acquires information in his/her professional sphere, it is through reading that professional terms are learned and professional communication established.

The next skill in line is academic speaking - being able to discuss professional topics, to take part in conferences and to make oral presentations.

Oral skills, the authors consider, should be developed by encouraging students to answer questions, discuss professional texts, make presentations about their own research - all on the basis of the material acquired by classroom and individual reading. (Шахова et al.1980: 5)

Bearing these priorities in mind, we will turn to discussing what kind of grammar should be taught to university students.

In the pre-perestroika Soviet Union students of technical higher education institutions were not especially encouraged to develop oral skills, their chance of traveling abroad being limited and communication with foreigners discouraged. They were taught to read, however, grammar being an auxiliary subject for developing reading skills. The grammar textbooks were mostly based on special lexis. (Зверева, Эбер, 1968; Мальчевская 1970; Михельсон 1989). Now the tide has turned and systematic grammar has been banished from textbooks focusing on developing oral conversational skills. In modern textbooks, grammar is presented in the form of a short reference section without emphasis on complex syntactic constructions or authentic examples. (Valdavina, Kuznetsova, 2003). Therefore the authors found it necessary to "restore grammar to its rights" to emphasize the importance of decoding grammar in the framework of tertiary ESP teaching.

\subsection{Chief Grammatical Phenomena Needing Special Explanation}

In this section, the authors will focus on some grammatical constructions causing difficulty for Russian students. The list may be different for speakers of other languages, depending on whether certain grammatical structures are present or absent in the students' native language.

\subsubsection{Passive Constructions}

Passive constructions are much more numerous in English than in Russian and defy word-for-word translation. It is especially true of sentences where the subject of the sentence denotes the recipient of the action (example 1) or those containing a preposition. (2)

1. Members of the parliament or legislature are granted partial immunity from prosecution.(Note 3)

2. Many materials now in common use were not even thought of thirty years ago.

Such sentences require explicit explanation and analysis.

4.2.2 Non-finite forms of the verb, such as the infinitive, the gerund and the participle. Their meaning doesn't transpire in word-for-word translation. For example such sentences as 
3. You have no doubt seen children whisper to themselves when they are beginning to read.

4. Levels of stress in the family have been shown to change with changing economic circumstances.

These structures will not be understood by a student having limited knowledge of English unless it is pointed out that they contain two predications: a) you have seen an event; b) children whisper to themselves. It is not until the sentence is split into two predications that its meaning becomes obvious to the student.

A similar procedure of analysis may be used for (4). The sentence is divided into two predications: a) levels of stress change, etc. b) the fact has been shown.

The perfect forms of the non-finites are also difficult to understand if they don't exist in the students' native language. For example:

5. The ancient building is known to have been erected 3000 years ago.

It is important to show to the students that the two predications: the building was erected three thousand years ago, and this fact is known refer to different periods of time.

\subsubsection{Modal Verbs}

Modal verbs are especially difficult for understanding if they are accompanied by the perfect forms of the infinitive, expressing probability (6) or unperformed action or event (7).

6. The ancient Hebrews may well have migrated from Ur sometime after 1950 B.C.

7. A nuclear war between the USA and the Soviet Union could have cost 40 million American lives, plus untold numbers of Soviet, Cuban and European casualties.

Other usages of modal verbs are also important, but these have been shown to cause most difficulties.

\subsubsection{Attributive Clauses}

Such structures are abundant in scientific, scholastic and political texts, serving as a means of compression. Whereas two-element phrases like telephone company or government official are usually easily understood, more complex phrases such as

8. The president's national security adviser

9. ...the civil rights and women's rights movements

require special explanation and demonstrative exercises, it being explained to the student that the last word in the chain is the head of the group, while the preceding nouns can serve as attributes to the main word or form smaller attributive groups within a larger one (see civil rights and women's rights in (9).

\subsubsection{Conversion}

Conversion being the main way of verbal word formation and producing new lexemes, it is important that students recognize it to understand the meaning of the sentence. Grammatical analysis helps to find which part of speech the lexeme belongs to and to avoid grammatical homonymy. See the examples:

10. Ethnic grievances and poverty fuel powerful nationalist passions.

11. The country is getting close to $80 \%$ of its electricity from the fossil fuel.

Comparing such sentences helps the student to establish the morphological nature of the word by means of parsing the sentence, finding the predicate and performing other analytical procedures.

The structures described above are not the only grammatical phenomena requiring analysis and special explanation. Standard textbooks contain such sections as conjunctions, subjunctive mood, pronouns, compound and complex sentences, etc. The teacher's choice also depends on the students' future profession, their knowledge grammar, the general syllabus, etc.

\subsection{The Main Types of Exercises Recommended for Studying Grammar}

Grammar studied in the framework of developing reading skills requires certain exercises aimed not only at developing understanding abilities, but also at extending the students' syntactic repertoire and thereby developing not only reading, but professional writing skills.

\subsubsection{Presentation and Translation Exercises}

In order to understand the meaning and functioning of a grammar structure, the student must be exposed to specially 
chosen materials illustrating its usage, preferably based on professional vocabulary. The most economical way of presenting such materials is in the form of individual sentences containing the structure being studied. It is desirable that students be asked to translate these examples into their native language. Translation from the foreign into the native language as part of grammar translation method used in teaching classical languages is the fastest and the most efficient way of securing understanding of a syntactic structure. Translation reveals the semantic structure of the sentence. At the initial stages, students tend to use literal translation techniques, disregarding the semantic structure of the sentence (Mat Awal, Zainudin 2009). What the teacher must do is to help the student "unpack" the sentence, analyze its semantic structure (for instance, pointing out two predications, like in (3) and (4) and then pack it into a different container - the syntax of the native language.

\subsubsection{Transformation Exercises}

This type of exercise requires the student to change the syntactic structure of the sentence, keeping its semantics intact. For example:

12. It is understood that the Prime Minister is holding talks with the opposition. - The Prime Minister is understood to be holding talks with the opposition.

13. Soon after the President was elected he launched his anti-drug campaign. - Soon after being elected, the president launched his anti-drug campaign.

14. A scientist who conducts such experiments must keep careful records. -A scientist conducting such experiments must keep careful records.

15. Experiments which are conducted in this laboratory yielded interesting results. -Experiments conducted in this laboratory yielded interesting results.

These transformative exercises are especially useful in studying infinitive constructions (6), gerundial (7) and participial $(8,9)$ phrases. Like translation exercises, they help the student to see the semantic structure of the sentence, but also teach active usage of complex grammatical constructions. The procedure resembles algebraic transformations and involves actually different ways of presenting information.

\subsubsection{Back Translation}

Translation from the native into the target language seems most useful as a final stage of studying a grammatical phenomenon and serves as a kind of bridge between teaching reading and writing skills. When one of the authors and her co-authors were writing a basic textbook for students of humanities, we asked our colleagues which types of exercises were most desirable. The answer was unanimous: translation from Russian. It is desirable that back translation exercises be based on the lexis contained in presentation exercises, encouraging the student to return to the previous parts of the material and find the necessary words. Back translation exercises enable the student to re-process the information received in the presentation and transformative exercises and to store the structures obtained for future academic speaking and writing.

Experience shows that at the first stages, sentences offered for back translation may be identical to those presented in earlier exercises. Later, however, more challenging materials can be offered, based on the lexis studied in other sections of the textbook or manual.

\subsection{Grammatical Analysis as a Key to New Lexis}

Contextual guessing is an important instrument in teaching reading comprehension (Amosova 1968, Siregar 2019), Hyönä and Lindeman 1994). Linguists distinguish lexical and syntactic context, the latter being a means to understand the meaning of a word based on its syntactic position, and to eliminate syntactic homonymy, that is belonging of identical words to different parts of speech (Amosova, 1968: 27, 53;).

In this paper, the authors would like to use the term "contextual derivation", because the understanding of an unfamiliar word is achieved by means of a formal syntactic analysis.

For example, predicates governing the infinitive usually have various modal meanings, such as obligation (to be obliged, to have), desire (to want, to wish), ability (to be able, to manage).

In this syntactic position, other predicates acquire modal meanings which they don't have in other contexts. (Sallier 2020). See the examples:

16. Having thus got rid of his two associates, Nigel was free to put certain questions which he didn't want either of them to hear. 
17. You are competent to run their culture center.

18. I didn't have the heart to throw the case away.

19. He burned to distinguish himself in battle

In (16) free means possibility caused by the absence of obstacles; In (17), competent means possibility created by the personal qualities of the subject; in (18), the absence of possibility is caused by emotional factors. In all cases, the modal meaning is conferred upon the predicate by the infinitive. In (19) the verb to burn means strong desire. So the predicates governing the infinitive become modals and if a special grammar exercise containing such structures is presented to the students, it will help them derive the modal meaning of the predicate from the context.

Another example of syntactic context affecting the meaning of a predicate is an object clause. See the examples:

20. I gathered that the guests were not going to stay for dinner.

21. Many teachers hold that the best age at which to begin learning a foreign language is that between the tenth and twelfth years.

22. Supporters of Franklin Roosevelt and the New Deal charged that much of the press was opposed to socioeconomic reform.

23. The report claimed that hundreds of civilians had crossed the border to escape the fighting.

In (20) gathered means "understood"; in (21) hold means "think, consider"; in (22) and (23) the verbs charged and claimed have a meaning of expressing an opinion or communicating a fact and they are, in this context, verbs of communication. These examples show that verbs governing an object clause have a limited range of meanings -acquiring (19), possessing $(20)$ and communicating $(21,22)$ information. The group includes verbs of perception, mental activity and speech. Lexemes with different meanings in other contexts acquire them when governing an object clause. If this contextual phenomenon is explained to the students and a suitable demonstrative exercise is presented, further understanding will be facilitated. (Cf. Салье et al, 2007, 171)

These examples show that some syntactic structures offer insights into lexical meaning, which enables the student to reduce the use of the dictionary and make reading more fluent.

\subsection{Compiling Materials}

This seems to be the most difficult problem facing the teacher. As has been shown, demonstrative exercises work best when based on the lexis belonging to the students' professional vocabulary. Some Russian textbooks based on scholastic (Мальчевская, 1970) or technical (Михельсон,1989) terms may be of use as far as English material is concerned. The teacher may encourage their students to find the structures being studied in their reading materials. A new sentence search engine https://ludwig.guru/s/ can also be helpful.

\section{Conclusions}

The research conducted makes it possible to draw the following conclusions:

- $\quad$ Professional reading is the most essential skill for ESP students.

- On the basis of academic reading, other linguistic skills can be developed - academic speaking and academic writing.

- No professional reading in a foreign language is possible without systematically learning grammar.

- Grammar translation method, modified and adapted to modern realities and combined with other teaching techniques is essential for teaching reading skills.

- Analyzing grammar structures can also stimulate contextual derivation, certain syntactic positions being filled by lexemes with a limited range of meanings.

- Various types of exercises can be used for teaching decoding grammar.

\section{References}

Amosova N. (1968). English contextology. Leningrad.

Borgmann Dmitri. (1967). Beyond Language: Adventures in Word and Thought. Charles Scribner's Sons. 
Grammar translation method. $\quad$ Retrieved $\quad$ Nov $12 \quad 2021$ from https://sites.google.com/site/theamazingworldofteaching/methods-and-approaches-in-elt/grammar-translation-m ethod

Hyönä Jukka Lindeman Johanna. (1994). Syntactic Context Effects on Word Recognition: A Developmental Study. Scandinavian Journal of Psychology, 35(1). https://doi.org/10.1111/j.1467-9450.1994.tb00930.x

Mat Awal Norsimah \& Zainudin Intan Safinaz. (2012). Teaching translation techniques in a university setting: problems and solutions. Procedia - Social and Behavioral Sciences, 46, 800-804. https://doi.org/10.1016/j.sbspro.2012.05.202

Murphy Raymond. (1997). English Grammar in Use. A self-study reference and practice book for intermediate students. Cambridge University Press.

Sallier Tatiana. (2020). Semantic Shifts Within Infinitive Constructions in English. Open Journal for Studies in Linguistics, 3(1). https://doi.org/10.32591/coas.ojs1.0301.03029s

Siregar Syamsiah Depalina. (2021). Contextual Guessing Technique in Reading. English Education English Journal for Teaching and Learning, 7(1), 29-44. https://doi.org/10.24952/ee.v7i01.1650

Valdavina S., \& Kuznetsova L. (2003). English for law students. Moscow.

Vince Michael. (2009). First certificate Language Practice. English Grammar and vocabulary. Macmillan education.

Зверева Е. Н., \& Эбер И. Г. (1968). Практический анализ английского предложения. Изд-во ленинградского университета.

Мальчевская Т. Н. (1970). Сборник упражнений по переводу гуманитарных текстов с английского языка на русский. Ленинград, изд-во «Наука».

Михельсон, Т. Н., \& Успенская Н. В. (1989). Сборник упражнений по основным разделам грамматики английского языка. Практическое пособие: Наука.

Салье Т. Е., Валиева Ю. М., \& Воскресенская И. Н. (2007). English for students of communications. Москва, Академия.

Шахова Н. И., Рейнгольд В. Г., Салистра В. И., Басс Э. М., Дезен Н. Б., Трущенко И. А., Бибанова И. Н., Ведерникова Д. В., Гуро Н. И., Дроздова М. Ф., Клещевникова Т. И., \& Рафес Н. П. (1980). Learn to read science: English for post graduate students. Moscow.

\section{Notes}

Note $1 . \quad$ See for example:

https://www.google.com/search?q=english+without+grammar\&oq=english+without + g\&aqs=chrome.1.69i57j0i1912j

0i19i22i3017.31936j0j15\&sourceid=chrome\&ie=UTF-8; https://www.youtube.com/watch?v=aThGVEARxaM

Note 2. See for example: Murphy 1994, Vince 2009

Note 3. All the examples have been taken from the textbook by Tatiana Sallier, Julia Valieva and Irina Voskresenskaya "English for students of communications" (Салье et al.2007) All the examples are authentic, having been borrowed from newspapers, books of fiction, the BBC and VOA materials and other sources.

\section{Copyrights}

Copyright for this article is retained by the author(s), with first publication rights granted to the journal.

This is an open-access article distributed under the terms and conditions of the Creative Commons Attribution license (http://creativecommons.org/licenses/by/4.0/). 